\title{
ARBUSCULAR MYCORRHIZA OF HERBS COLONIZING A SALT AFFECTED AREA NEAR KRAKÓW (POLAND)
}

\author{
BARBARA GRZYBOWSKA \\ Institute of Botany of the Jagiellonian University \\ Lubicz 46, 31-512 Kraków, Poland \\ e-mail: b.grzybowska@uj.edu.pl
}

(Received: September 10, 2003. Accepted: February 20, 2004)

\begin{abstract}
The arbuscular mycorrhizal (AM) status of plants colonizing an area affected by leakage of salty water (Barycz near Kraków, Poland) was studied in 2000 and 2001. The occurrence of plants typical for soils of increased salinity was observed. Among the 13 examined plant species 7 were mycorrhizal. The abundance of mycorrhizal plant populations was increased in the second year of study. Strains of 4 species of AMF, including Glomus caledonium, G. claroideum, G. geosporum and G. intraradices were isolated using trap cultures. On the basis of morphological characters the presence of $G$. tenue was detected in plant roots of several species from the study area. The efficiency of mycorrhizal colonization and arbuscule formation by two strains of G. geosporum isolated from a saline area and a strain of $G$. intraradices from unaffected sites was tested in an experiment carried out on Plantago lanceolata cultivated on substrata of different salinity levels. The increase in mycorrhizal parameters with growing salt content was observed in the case of strains originating from the salt-affected area. At the highest salt level these strains formed better developed mycorrhiza than the strain from the non-saline site, suggesting a better adaptation of the strains from the saline area. The data on vitality (alkaline phosphatase test) of intraradical AM fungi gave a clearer picture than those obtained by the conventional aniline blue staining.
\end{abstract}

KEY WORDS: arbuscular mycorrhiza, AMF, salinity, halophytes, glycophytes, alkaline phosphatase test.

\section{INTRODUCTION}

Salt-affected soils cover almost $10 \%$ of the global land surface (Ruiz-Lozano et al. 1996), including salt marshes of the temperate zones, mangrove swamps of the tropics and subtropics and saline soils of arid and semiarid zones where the amount of rainfall is insufficient for substantial leaching. The origin of soil salinity can be natural, due to climate conditions, or caused by human activity, such as mining or application of salt for deicing (Blassius and Merritt 2002). Salinity inhibits growth and development of most plants. It affects growth, morphology and physiology of roots; however, adaptation to this particular stress condition can be observed in plants occurring on soils of increased salinity (Kopcewicz and Lewak 1998; Volkmar et al. 1998). The development of a symbiosis with microorganisms such as arbuscular mycorrhizal fungi (AMF) may be one of the mechanisms that can attenuate the stress by compensation of the soil volume for nutrient acquisition, reduction of the negative osmotic pressure and imbalance of essential cations and anions, alteration of the $\mathrm{pH}$ and soil structure (Schwarz and Gale 1984; Hasegawa et al. 1986). Rhizospheric microorganisms have been found in soils containing up to $30 \%$ of $\mathrm{NaCl}$ (Zahran 1996). Arbuscular mycorrhizal fungi isolated from such soils have been found to improve growth and fitness of the plants (Hirrel and Gerdemann 1980; Ojala et al. 1983; Singh et al. 1997; Al-Karaki and Hammad 2001; Feng et al. 2002). Inoculum containing selected strains can be used e.g. for alleviation of stress to grasses colonizing road sides that have been treated with salt during winter. Production of such inoculum should include strains originating from the same geographic region and adapted to the particular climatic and soil conditions.

The present investigation was carried out in the area affected by leakage of salt from tubes transporting waste-water from the salt mine near Kraków and water pumped out from the salt mine during the failure that happened a few years ago. The salt effect was still visible, as characteristic halophytic vegetation was present at this site. The aims of this research were: 1) evaluation of the mycorrhizal status of herbs to check the ability of the fungal strains to form functional symbiosis under a range of soil salinity levels; 2) isolation and identification of the AMF strains; 3) evaluation of the ability of selected strains to form mycorrhiza under salt stress. 


\section{MATERIALS AND METHODS}

\section{Site description and sample collection}

The salt-affected region is located on the northern slope of Pogórze Wielickie (southern Poland), between two villages Barycz and Soboniowice (in the vicinity of Kraków), near the communal rubbish dump. The area of approximately $1000 \mathrm{~m}^{2}$, developed in the place where originally oakhornbeam wood Tilio-Carpinetum was present on brown soil (Dubiel 1988). The salinity of soil at the sampling area was caused by brine leak from the pipeline delivering the saline water from the salt mine to the tank (reservoir) located at the site. The vegetation on the area affected by the saline water was dominated by halophytic plant species such as Puccinellia distans (Jacq.) Parl and Spergularia salina Presl. They were accompanied by glycophytes.

The study was carried out during the flowering period in June 2000 and 2001. The plant material was collected from 6 plots (about $16 \mathrm{~m}^{2}$ each) chosen randomly at the site. The identification of plant species was carried out during the first vegetative season. The plant percentage cover was estimated according to the 6-degree Braun-Blanquet scale (Szafer and Zarzycki 1970). Roots of 5 specimens of each plant species were collected from the individual plots and were pooled into a single bulk sample. Plant roots with adhering soil were collected and used for the establishment of trap cultures. Samples for soil analysis were collected from three randomly chosen points of each plot to the depth of $15 \mathrm{~cm}$, and mixed thoroughly. Table 1 summarizes some of the soil chemical and physical properties: electrical conductivity (EC) of the saturation paste extract (Richards 1954), $\mathrm{pH}$ with $\mathrm{H}_{2} \mathrm{O}(1: 2.5 \mathrm{w} / \mathrm{v})$ (Kowalkowski et al. 1973), concentration of the $\mathrm{Cl}^{-}, \mathrm{Na}^{+}, \mathrm{K}^{+}, \mathrm{Ca}^{+2}$ ions (Ostrowska et al. 1991), organic carbon and organic matter content (Lityński et al. 1968).

\section{Estimation of mycorrhizal colonization}

Roots were rinsed with water, cleared in $10 \% \mathrm{KOH}$ for 24 hours, acidified in 5\% lactic acid for 1 hour, stained in $0.01 \%$ aniline blue (in 5\% lactic acid) for 24 hours and stored in pure lactic acid. The procedure was followed at room temperature. The roots were cut into $1 \mathrm{~cm}$ pieces $(45$ pieces per sample), mounted on slides in glycerol and analysed with the Nikon Eclipse 800C light microscope. The following mycorrhizal parameters were assessed: mycorrhizal frequency $(\mathrm{F} \%)$, relative $(\mathrm{M} \%)$ and absolute $(\mathrm{m} \%)$ mycorrhizal root length, relative $(\mathrm{A} \%)$ and absolute $(\mathrm{a} \%)$ arbuscule richness (Trouvelot et al. 1986), http: //www.dijon.inra.fr.bbceipm/Mychintec/Mycocalc-prg/download.html.

\section{Isolation of AMF strains}

Soil samples (including plant roots) collected from the rhizosphere of plants growing in the investigated area were placed in pots containing sterile substratum (sand: expanded clay $3: 1, \mathrm{v} / \mathrm{v}$ ) containing $50 \mathrm{~g}$ of phosphate rock per 11 of the substratum and covered by $1 \mathrm{~cm}$ layer of the substratum. The cultures were kept in Sigma sunbags in greenhouse conditions using Plantago lanceolata $\mathrm{L}$. as host plant (10 seedlings per pot). Pots were watered to the point of saturation and the humidity was maintained according to Walker (personal communication). After three months spores were isolated using wet filtering (mesh size $50 \mu \mathrm{m}$ ).

Identification of the AM fungi was carried out on material obtained from single spore cultures. Isolated spores were germinated on cellulose filters on a layer of wet sterile sand in Petri dishes. A single germinating spore was attached to the root of a Plantago lanceolata seedling and they were put together in a small pot containing sterile substratum (sand and expanded clay 1:1, v/v), and watered. After 3 months the substratum with AMF mycelium from the small pots was moved to bigger pots with the same sterile substratum and more seedlings were planted to multiply the AMF inoculum for next three months. Spores isolated from monocultures were mounted in a drop of PVLG and Meltzer's reagent on a slide and crushed to examine the wall structure by applying gentle pressure to the coverslip (Omar et al. 1979). Slides with isolated spores were deposited in the slide collection of the Institute of Botany of the Jagiellonian University.

\section{Estimation of mycorrhizal efficiency of AMF strains}

Three different AMF strains: two strains of Glomus geosporum originating from the saline soil near Barycz and Glomus intraradices (BEG Rej. E-1 99/Lav.) from non-saline soil, were used to inoculate Plantago lanceolata. This species was selected as most commonly occurring at road sides affected by salt stress. Additionally, this plant forms mycorrhiza with a wide range of AMF strains/species and is easily grown under laboratory conditions. Four growth substrates differing in salt content (EC) were applied: saline soil collected at the site $(24.70 \mathrm{mS} / \mathrm{m})$, nonsaline soil $(3.92 \mathrm{mS} / \mathrm{m})$ and two other substrata consisting of saline soil diluted by the nonsaline soil in proportions $3: 1$ $\mathrm{v} / \mathrm{v}(9.98 \mathrm{mS} / \mathrm{m})$ and $1: 1 \mathrm{v} / \mathrm{v}(11.82 \mathrm{mS} / \mathrm{m})$. One liter of expanded clay with $200 \mathrm{~g}$ of phosphate rock were added per each three liters of the growth substratum. 10 seedlings were cultivated in each pot (volume $500 \mathrm{~cm}^{3}$ ). Pots were kept in Sigma sunbags and the humidity maintained as described above. After 8 weeks the plants were removed from the pots. Roots of 3 randomly chosen plants growing

TABLE 1. Physical and chemical properties of soil in the salt-affected area near Barycz.

\begin{tabular}{|c|c|c|c|c|c|c|c|c|}
\hline \multirow{2}{*}{ Plot number } & \multirow{2}{*}{$\mathrm{pH}^{\mathrm{a}}$} & \multirow{2}{*}{$\begin{array}{c}\mathrm{EC}^{\mathrm{b}} \\
\mathrm{mS} / \mathrm{m}\end{array}$} & $\mathrm{Cl}^{-}$ & $\mathrm{Na}^{+}$ & $\mathrm{K}^{+}$ & $\mathrm{Ca}^{2+}$ & Organic matter & Organic carbon \\
\hline & & & \multicolumn{4}{|c|}{$\mathrm{mg} / 100 \mathrm{~g}$ of dry soil } & \multicolumn{2}{|c|}{$\%$} \\
\hline 1 & 6.45 & 10.62 & 68 & 125 & 5 & 200 & 3.37 & 1.96 \\
\hline 2 & 6.87 & 11.77 & 43 & 155 & 15 & 570 & 4.58 & 2.65 \\
\hline 3 & 6.89 & 12.29 & 28 & 125 & 12 & 500 & 4.14 & 2.40 \\
\hline 4 & 6,40 & 18.95 & 42 & 150 & 20 & 1000 & 3.51 & 2.07 \\
\hline 5 & 6.75 & 26.30 & 42 & 185 & 15 & 310 & 2.88 & 1.67 \\
\hline 6 & 6.89 & 31.20 & 76 & 210 & 20 & 870 & 5.21 & 3.02 \\
\hline
\end{tabular}

a with $\mathrm{H}_{2} \mathrm{O}$

b electric conductivity 
at each salinity level were stained for the activity of alkaline phosphatase. Remaining plant roots were stained in aniline blue as described above. The roots for the estimation of the activity of alkaline phosphatase were stained according to Van Aarle et al. (2001). The roots were washed in tap water, cut into $1 \mathrm{~cm}$ pieces (45 per sample), mounted on slides and stained for $15 \mathrm{~min}$ with the ELF 97 Endogenous Phosphatase Detection Kit (Molecular Probes). After staining the roots were washed in the wash buffer $(30 \mathrm{mM}$ Tris, $1.5 \mathrm{M} \mathrm{NaCl}$ and $0.05 \%$ Triton $\mathrm{X}-100, \mathrm{pH} 8$ ) for 15 min before the mounting medium from the kit was applied and the slides were closed with coverslips. The roots were analysed with a Nikon Eclipse $800 \mathrm{C}$ fluorescence microscope equipped with a mercury lamp and the mycorrhizal parameters were assessed as described above.

\section{Statistics}

Data for mycorrhizal parameters were analysed with the non-parametric U-Mann Whitney test $(\mathrm{p}<0.05)$. The analyses were performed using STATISTICA (version 5.0) software.

\section{RESULTS}

The vegetation of the investigated plots consisted of 13 species (Table 2). Comparing the species composition on the plots during the two seasons of investigation, 2000 and 2001 , it was found that the population of some mycorrhizal species increased and appeared on a higher number of plots (e.g. Matricaria chamomilla L., Plantago maior L., Trifolium repens $\mathrm{L}$. and Tussilago farfara $\mathrm{L}$.). The new mycorrhizal species in 2001, not occurring in the previous season, was Ranunculus repens L. In contrast, Lotus spp. L. disappeared. Non-mycorrhizal species such as Agropyron repens (L.) P. B., Atriplex hastatum L. var. salinum and Lepidium ruderale $\mathrm{L}$. were absent on the site in the second year of the study (Table 2).

On the selected plots, similarly to the whole area, the most abundant plants were Puccinellia distans and Spergularia salina (Table 3). In both cases no mycorrhizal struc-

TABLE 2. Species composition of plots and mycorrhizal status of plants at the salt-affected site near Barycz; np - not present in this year.

\begin{tabular}{llcc}
\hline & & \multicolumn{2}{c}{$\begin{array}{c}\text { Plot number } \\
\text { where occurred }\end{array}$} \\
\cline { 2 - 4 } Plant species & Family & in 2000 & in 2001 \\
\hline non-mycorrhizal & & 1 & $\mathrm{np}$ \\
Agropyron repens & Graminae & 1 & $\mathrm{np}$ \\
Atriplex hastatum var. salinum & Chenopodiaceae & 1 & $\mathrm{np}$ \\
Lepidium ruderale & Brassicaceae & $1,2,3,4,5,6$ & $1,2,3,4,5,6$ \\
Puccinellia distans & Gramineae & $2,3,5,6$ & $2,3,5,6$ \\
Spergularia salina & Caryophyllaceae & 4 & 4 \\
Typha latifolia & Typhaceae & & \\
& & & \\
mycorrhizal & & 1 & $\mathrm{np}$ \\
Lotus spp. & Fabaceae & $\mathrm{np}$ & 1,3 \\
Ranunculus repens & Ranunculaceae & 3 & $2,3,6$ \\
Matricaria chamomilla & Asteraceae & 1 & 3 \\
Melilotus officinalis. & Fabaceae & $1,2,3,4,5$ & $1,2,3,4,5,6$ \\
Plantago maior & Plantaginaceae & 4,6 & $2,4,5,6$ \\
Trifolium repens & Fabaceae & 3 & $1,3,4,5,6$ \\
Tussilago farfara & Asteraceae & & \\
\hline
\end{tabular}

TABLE 3. Species abundance, relative mycorrhizal root length (M\%) and relative arbuscule richness (A\%) of plants on different plots at the saltaffected site near Barycz (values listed are means \pm standard deviation, number of samples from 4 to 6 depending on availability of material) Each species abundance in the plot was estimated according to the 6degree Braun-Blanquet scale: \pm the species covers up to $1 \%$ of the area; 1 - the species covers up to $5 \% ; 2$ - the species covers 5 to $25 \% ; 3$ - the species covers 25 to $50 \% ; 4$ - the species covers 50 to $75 \%$; 5 - the species covers 75 to $100 \%$.

\begin{tabular}{|c|c|c|c|}
\hline Plant species & $\begin{array}{c}\text { Species } \\
\text { abundance }\end{array}$ & $\begin{array}{l}\mathrm{M} \\
\%\end{array}$ & $\begin{array}{l}\mathrm{A} \\
\%\end{array}$ \\
\hline \multicolumn{4}{|l|}{ Plot 1} \\
\hline Agropyron repens & + & 0.0 & 0.0 \\
\hline Atriplex hastatum var. salinum & 1 & 0.0 & 0.0 \\
\hline Lepidium ruderale & + & 0.0 & 0.0 \\
\hline Puccinellia distans & 3 & 0.0 & 0.0 \\
\hline Spergularia salina & 3 & 0.0 & 0.0 \\
\hline Lotus spp. & + & $71.6 \pm 19.5$ & $32.4 \pm 14.5$ \\
\hline Melilotus officinalis & + & $60.1 \pm 11.4$ & $34.0 \pm 6.5$ \\
\hline Plantago maior & 2 & $81.0 \pm 6.5$ & $42.0 \pm 23.8$ \\
\hline Ranunculus repens & + & $80.4 \pm 3.4$ & $18.2 \pm 9.1$ \\
\hline Tussilago farfara & 1 & $52.5 \pm 9.8$ & $23.0 \pm 5.6$ \\
\hline \multicolumn{4}{|l|}{ Plot 2} \\
\hline Puccinellia distans & 3 & 0.0 & 0.0 \\
\hline Spergularia salina & 2 & 0.0 & 0.0 \\
\hline Matricaria chamomilla & 2 & $67.6 \pm 17.6$ & $32.2 \pm 17.5$ \\
\hline Melilotus officinalis & + & $56.3 \pm 17.5$ & $18.1 \pm 6.1$ \\
\hline Plantago maior & 2 & $66.7 \pm 19.8$ & $36.6 \pm 9.4$ \\
\hline Trifolium repens & 2 & $90.0 \pm 2.9$ & $42.0 \pm 9.0$ \\
\hline \multicolumn{4}{|l|}{ Plot 3} \\
\hline Puccinellia distans & 3 & 0.0 & 0.0 \\
\hline Spergularia salina & 3 & 0.0 & 0.0 \\
\hline Plantago maior & 2 & $74.2 \pm 15.8$ & $96.6 \pm 5.9$ \\
\hline Ranunculus repens & + & $52.3 \pm 10.1$ & $27.2 \pm 4.3$ \\
\hline Tussilago farfara & 2 & $52.6 \pm 12.0$ & $19.2 \pm 8.0$ \\
\hline \multicolumn{4}{|l|}{ Plot 4} \\
\hline Puccinellia distans & 2 & 0.0 & 0.0 \\
\hline Typha latifolia & 1 & 0.0 & 0.0 \\
\hline Plantago maior & 1 & $69.1 \pm 19.1$ & $31.7 \pm 11.3$ \\
\hline Trifolium repens & 2 & $77.7 \pm 1.6$ & $37.2 \pm 7.6$ \\
\hline Tussilago farfara & 1 & $67.7 \pm 7.3$ & $23.6 \pm 6.3$ \\
\hline
\end{tabular}

Plot 5

$\begin{array}{llll}\text { Puccinellia distans } & 3 & 0.0 & 0.0\end{array}$

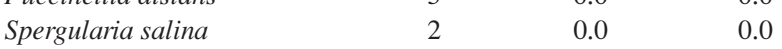

$\begin{array}{llll}\text { Plantago maior } & 1 & 66.3 \pm 11.7 & 26.4 \pm 17.7\end{array}$

$\begin{array}{llll}\text { Trifolium repens } & 2 & 65.9 \pm 4.7 & 27.4 \pm 3.8\end{array}$

$\begin{array}{llll}\text { Tussilago farfara } & 2 & 43.2 \pm 31.1 & 16.8 \pm 12.6\end{array}$

Plot 6

Puccinellia distans

Spergularia salina

Matricaria chamomilla

Plantago maior

Trifolium repens

Tussilago farfara

$\begin{array}{cc}0.0 & 0.0 \\ 0.0 & 0.0 \\ 63.7 \pm 13.6 & 44.7 \pm 10.7 \\ 61.3 \pm 13.6 & 49.0 \pm 35.9 \\ 86.8 \pm 6.4 & 50.7 \pm 19.9 \\ 60.5 \pm 23.4 & 32.4 \pm 11.1\end{array}$

tures were found. Nonmycorrhizal were also other species of Gramineae, Chenopodiaceae, Brassicaceae and Caryophyllaceae which were, however, less common. Mycorrhizal structures were observed in roots of Asteraceae, Fabaceae, Ranunculaceae and Plantaginaceae (Table 2). Plantago maior was one of the most abundant mycorrhizal plants, followed by Trifolium repens and Tussilago farfara. (Table $3)$. The degree of mycorrhizal frequency $(\mathrm{F} \%)$ in roots of 

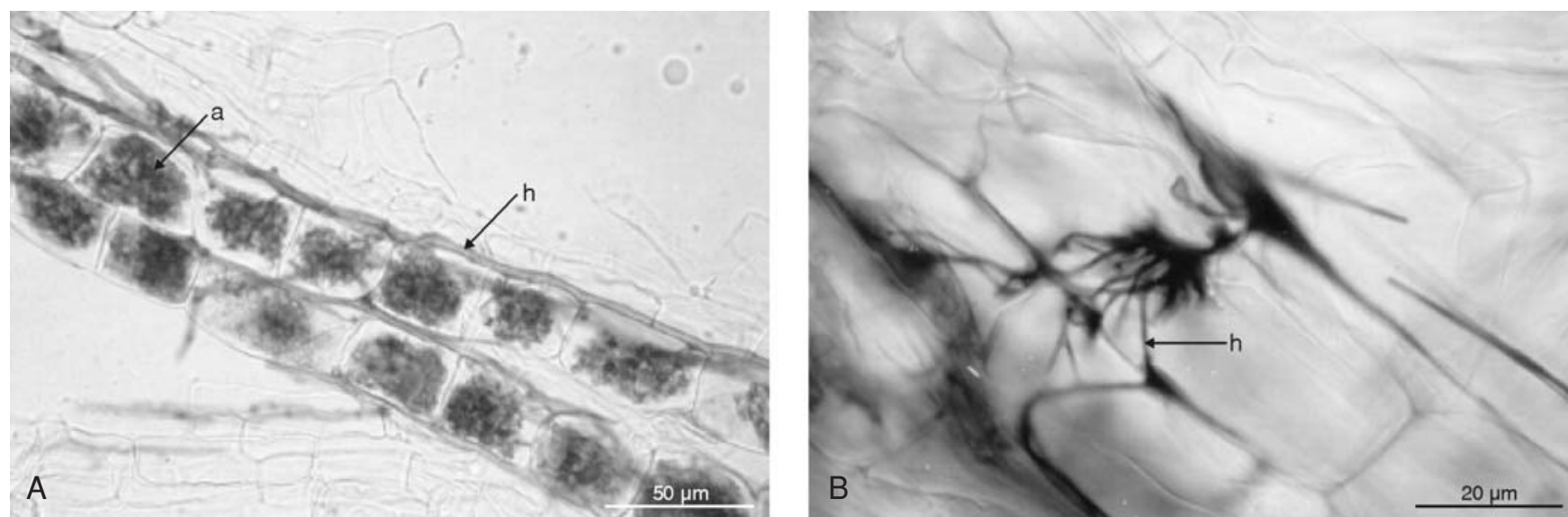

Fig. 1. Mycorrhizal colonization of Plantago maior collected from the salt affected area near Barycz: A - coarse endophyte with arbuscules (a) and intracellular hyphae (h); B - fine endophyte with typical finger-like branching of hyphae (h).
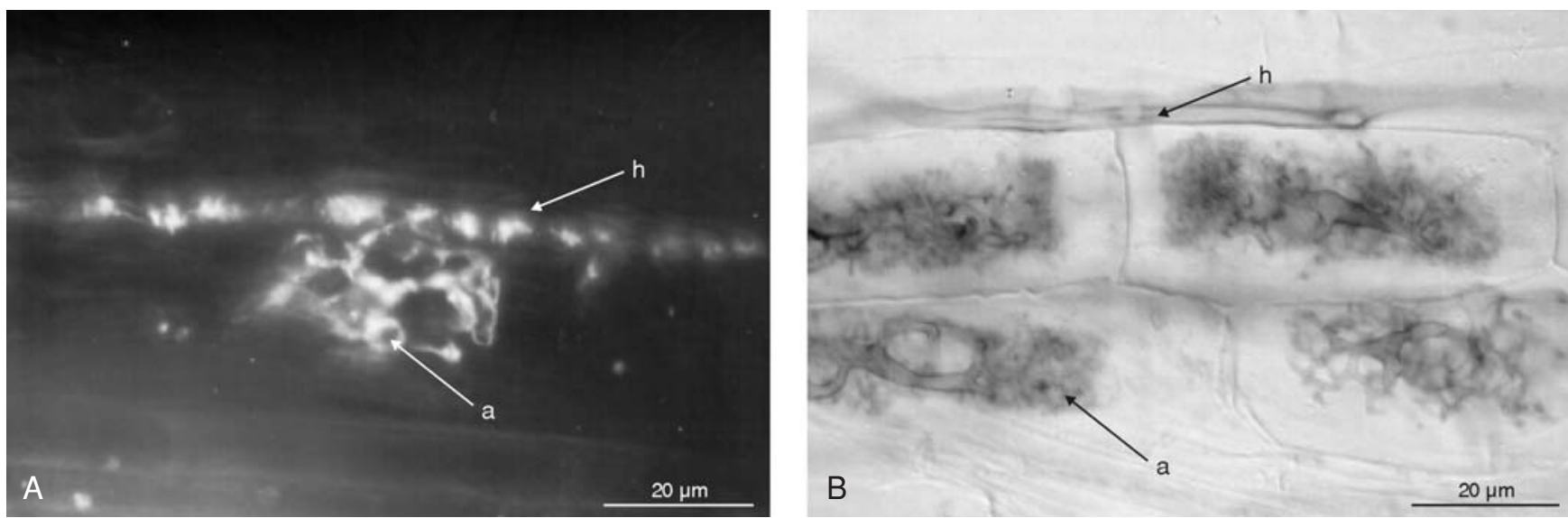

Fig. 2. Comparison between two staining methods used to detect mycorrhiza of Plantago lanceolata grown experimentally in salt affected soil: A - alkaline phosphatase test showing arbuscules (a) and hyphae (h) due to positive reaction of vacuoles; B - conventional aniline blue staining visualising mycelial walls.

all species varied between 86 and $100 \%$ in 2000 and 67 to $100 \%$ in 2001. Relative mycorrhizal root length (M\%) and intensity of colonization in individual mycorrhizal roots (m\%) were the highest in Plantago maior in 2000 and in Trifolium repens in 2001. Arbuscules were most abundant (a\%) in Melilotus officinalis (L.) Lam in 2000 and in Plantago maior in 2001 (data not shown).

Within roots of plants collected from the investigated area both coarse (Fig. 1A) and fine mycorrhizal fungi (Fig. 1B) were observed. On the basis of mycelium characteristics (finger-like branching of mycelium of about $2 \mu \mathrm{m}$ diameter with abundant, small vesicles) the fungus was identified as Glomus tenue (Greenhall) Hall. The species was noticed in Lotus spp. and Trifolium repens in the first year and additionally in Matricaria chamomilla and Melilotus officinalis in the second year. The fine endophyte was not obtained from the trap cultures. On the contrary, this method resulted in obtaining isolates of G. caledonium (Nicol. \& Gerd.) Trappe \& Gerd., G. claroideum Schenck \& Smith; G. geosporum (Nicol. \& Gerd.) Trappe \& Gerd.; G. intraradices Schenck \& Smith. The most frequently isolated were strains of $G$. geosporum.

The results of the experiment in which two strains of $G$. geosporum isolated from salt affected area near Barycz and a strain of $G$. intraradices originating from non-affected soils were used to inoculate Plantago lanceolata seedlings cultivated at different salinity levels are presented in Figures 3 and 4. Some differences among strains were shown in mycorrhizal parameters, although no visible differences in growth were found between plants inoculated with different strains and cultivated at various salt concentrations (data not shown). Almost no differences were found in mycorrhizal colonization levels in samples stained with aniline blue. Statistically higher mycorrhizal colonization was found in the case of strains originating from the salt affected site than from the nonsaline soil, especially at the highest salt concentration; the differences were more pronounced when the phosphatase activity method was used (Figs 2A and 4). The relative arbuscule richness estimated after aniline blue staining (Figs $2 \mathrm{~B}$ and 3 ) has shown differences between fungal strains of different origin only at the highest salt content and was much lower in the case of the strain from non-affected place. Similar tendencies were visible in data for the alkaline phosphatase activity (Fig. 4). In the case of both staining methods differences were found also between the two strains from the salt affected site and in addition the tendency to increase mycorrhizal colonization and arbuscule richness by the strains from salt affected areas was observed (Figs 3 and 4).

\section{DISCUSSION}

Arbuscular mycorrhiza (AM) represents a common rootfungus symbiosis in $80 \%$ of the higher plants in a wide range of environments (Smith and Read 1997). The AM 

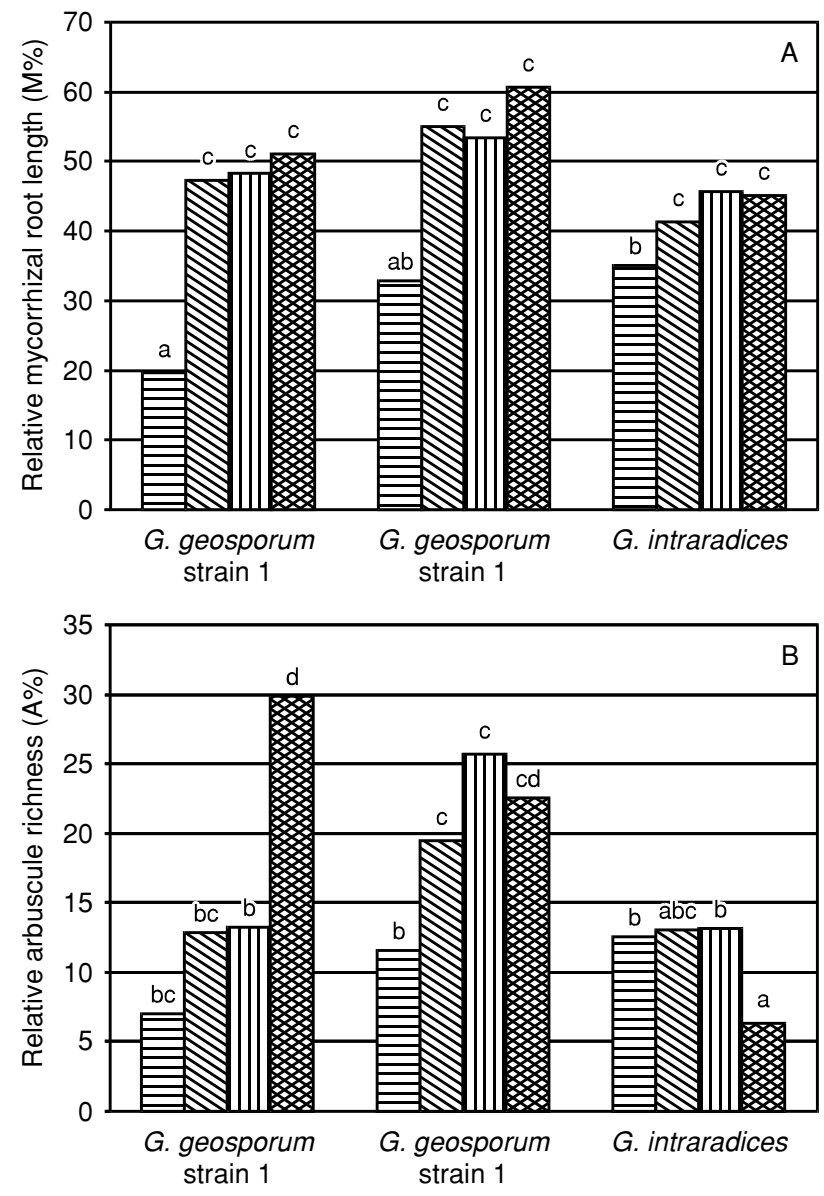

salinity level

$3.92 \mathrm{mS} / \mathrm{m} 9.98 \mathrm{mS} / \mathrm{m}$ Wس $11.82 \mathrm{mS} / \mathrm{m} 24.70 \mathrm{mS} / \mathrm{m}$

Fig. 3. Mycorrhizal parameters of Plantago lanceolata inoculated by $G$. geosporum strains originating from the salt affected soil and G. intraradices from non-affected soils, cultivated in substrata of increasing salt level - data estimated on the basis of aniline blue staining: A - relative mycorrhizal root length (M\%) and B - relative arbuscule richness (A\%). Different letters above bars indicate statistically important differences between all bars $(\mathrm{p}<0.05)$.

fungi have been shown by several workers to occur naturally in saline environments (Khan 1974; Allen and Cunningham 1983; Pond et al. 1984; Rozema et al. 1986; Ho 1987; Błaszkowski 1993; Aliasgharzaden et al. 2001; Bothe et al. 2001; Landwehr et al. 2002). The literature concerning mycorrhizal colonization of halophytes is controversial. Plants of wetland and saline sites were described not to be colonized by AMF (Smith and Read 1997). The halophilous species belonging to the families Chenopodiaceae, Plumbaginaceae, Juncaceae, Brassicaceae etc. were considered to be non-mycorrhizal (Hirrel et al. 1987; Smith and Read 1997) On the contrary, some halophytes have been found to be colonized by AMF (Mason 1928; Khan 1974; Hildebrandt et al. 2001). According to Hildebrandt et al. (2001), Spergularia salina (Caryophyllaceae) showed distinct colonization (2-14\% of colonization) and the halophytic grass Puccinellia distans was characterized by variable pattern of mycorrhizal colonization (0-49\%). Both species were examined for mycorrhization during the seed formation period and after the reproductive phase. In the present study plants belonging to the families Brassicaceae,
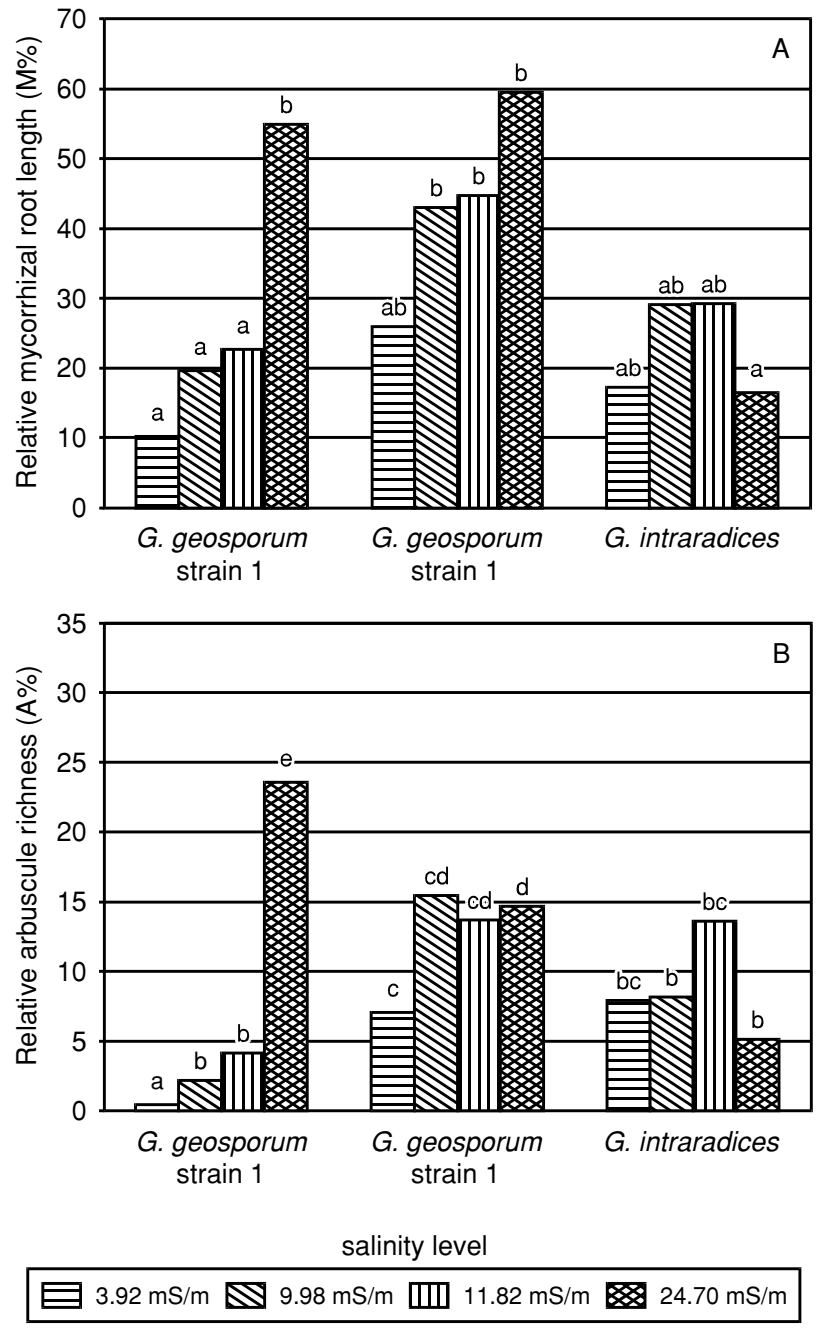

Fig. 4. Mycorrhizal parameters of Plantago lanceolata inoculated by $G$. geosporum strains originating from the salt affected soil and $G$. intraradices from non-affected soils, cultivated in substrata of increasing salt level - data estimated on the basis of alkaline phosphatase activity: A - relative mycorrhizal root length (M\%) and $\mathrm{B}$ - relative arbuscule richness (A\%). Different letters above bars indicate statistically important differences between all bars $(\mathrm{p}<0.05)$.

Gramineae, Caryophyllaceae were found to be non-mycorrhizal; however, the presence of mycorrhizal structures was verified during the flowering phase. The ability to form mycorrhiza should be checked, however, during the whole vegetation season, including all development stages of the plant, as the degree of mycorrhizal colonization can vary in individual plants during the vegetation period (Smith and Read 1997) or it could depend on other parameters of the soil. Atriplex hastatum var. salinum was reported as nonmycorrhizal by Rozema et al. (1986) and these data were confirmed in the present paper.

The present study reports that plants from the families Fabaceae, Asteraceae, Plantaginaceae, Ranunculaceae were found to be arbuscular mycorrhizal in a high degree. Some mycorrhizal species, e.g. Matricaria chamomilla and Tussilago farfara tended to be expansive in the area, while some of halophytic non-mycorrhizal plants showed an opposite tendency what is an obvious sign of decreasing salt level.

In the present study the isolated and identified AM fungal species were members of the genus Glomus with dominating G. geosporum. These data are in agreement with 
previous results of other workers (Allen and Cunningham 1983; Pond et al. 1984; Ho 1987). In a recent study of salt marshes in Central Europe $80 \%$ of isolated AM spores belonged to G. geosporum (Bothe et al. 2001; Hildebrandt et al. 2001; Landwehr et al. 2002).

The experiment carried out within this study has shown that AM fungi originating from the salt affected stand more efficiently colonized the roots developing in soils of higher salinity than those from non-affected ones. The differences were evident at the highest salinity of growth substratum. The strains of G. geosporum (from saline soils) produced also more abundant arbuscules than $G$. intraradices. This suggests better adaptation of the species/strains from saline areas to salt stress conditions occurring in such places and confirms the usefulness of the strain selection for the use in practical application. In addition, the experiment has shown the increase of mycorrhizal colonization and arbuscule richness by $G$. geosporum with increasing salt level. These data are in accordance with the field observations of Füzy et al. (2001), who found higher mycorrhizal colonization and more abundant arbuscule development in roots of Matricaria chamomilla and Festuca pseudovina at the more salty area.

In the present study no statistically important differences in growth of $P$. lanceolata inoculated with different strains of AM fungi and cultivated at different salt concentrations were found. This suggests that this particular plant species is relatively tolerant to salt. Higher salt levels could be tested but this would be not comparable to levels usually found at the road sides. The research aiming at the protection of plant diversity should consider a broader range of plant species that can react to salt in various ways. The response of individual plant species to different fungal species could vary as well. As shown by Ruiz-Lozano and Azcon (2000) in the experiment concerning inoculation of Lactuca sativa with AMF strains originating from saline soils, these strains formed more abundant mycorrhizal structures and stimulated root development, whereas the strain G. deserticola originating from non-saline soils improved plant nutrition. Both AM fungi, however, protected the host from salinity stress.

Both methods of staining applied in this study were useful to detect differences in fungal colonization; however, in the case of data obtained with the vitality method relying on the estimation of alkaline phosphatase activity the differences were more significant, suggesting higher sensitivity of this method. The same vitality method was also found to be the best method to select the most effective mycorrhizal strain for the colonization of heavy metal polluted soils (Orłowska et al. in press).

The strains isolated from the area near Barycz might be of interest for the practical application of AMF inoculum on roadsides, where soils are treated with salt for deicing during winter time. The levels of salinization may reach similar concentrations as those observed in the studied area. AMF are especially important in such environments, as they are considered as bio-ameliorators of saline soils (Singh et al. 1997). Several studies demonstrated that the inoculation with AMF improves plant growth under salinity stress (see Feng et al. 2002 for references). The attenuation of stress was suggested to be related to the improvement of plant phosphorus status (Hirrel and Gerdemann 1980; Al-Karaki 2000), increased carbon dioxide exchange rate, transpiration, stomatal conductance and water use efficiency (Ruiz-Lozano et al. 1996), or to higher accumulation of soluble sugars in roots (Feng et al. 2002). The selection of the most effective strains for practical application is important as the symbiotic efficiency and mycelial infectivity can vary between AMF strains isolated from saline and non-saline soils (Ruiz-Lozano and Azcon 2000). Future work has to show whether the AMF strains originating from soils near Barycz confer salt tolerance to plants.

\section{ACKNOWLEDGEMENTS}

The author is deeply obliged to Prof. Helena TrzcińskaTacik (Institute of Botany of the Jagiellonian University, Kraków, Poland) for indicating the interesting area and her help in field work. The identification of AMF strains by Prof. Janusz Błaszkowski (University of Agriculture, Szczecin, Poland), helpful critical comments on the manuscript by Prof. Katarzyna Turnau and useful suggestions and linguistic improvements to the manuscript made by Dr. Anna Jurkiewicz (Institute of Botany of the Jagiellonian University, Kraków, Poland) are gratefully acknowledged. The present work was supported by the EC project MYCOREM (QLK 3-1997-00097). The equipment used in this work was generously donated by the Foundation for Polish Science (FNP) Regle 25/97 and Subin 2000.

\section{LITERATURE CITED}

ALIASGHARZADEN N., SALEH RASTIN N., TOWFIGHI H., ALIZADEH A. 2001. Occurrence of arbuscular mycorrhizal fungi in saline soils of the taibriz Plain of Iran in relation to some physical and chemical properties of soil. Mycorrhiza 11: 119-122.

AL-KARAKI G.N., HAMMAD R. 2001. Mycorrhizal influence of fruit yield and mineral content of tomato grown under salt stress. J. Plant Nutr. 24: 1311-1323.

AL-KARAKI G.N. 2000. Growth of mycorrhizal tomato and mineral acquisition under salt stress. Mycorrhiza 10: 51-54.

ALLEN E.B., CUNNINGHAM G.L. 1983. Effect of vesicular-arbuscular mycorrhizae on Distichlis spicata under three salinity levels. New Phytol. 93: 227-236.

BLASSIUS B.J., MERRITT R.W. 2002. Field and laboratory investigations on the effects of road salts $(\mathrm{NaCl})$ on stream macroinvertebrate communities. Environmental Pollution 120: 219-231.

BŁASZKOWSKI J. 1993. The occurrence of arbuscular fungi and mycorrhizae (Glomales) in plant communities of maritime dunes and shores of Poland. Bull. Polish Acad. Sci. 41 (4): 377-392.

BOTHE H., HILDEBRANDT U., OUZIAD F., LANDWEHR M., NAWRATH K. 2001. The colonisation of plants from Central European heavy metal soils and salt marshes by arbuscular mycorrhizal fungi. Minerva Biotech. 13: 65-67.

DUBIEL E. 1988. Szata roślinna Krakowa. In: Trafas K. (ed.) Atlas miasta Krakowa. PPWiK, Kraków-Wrocław. p 15.

FENG G., ZHANG F.S., LI X.L., TIAN C.Y., TANG C. 2002. Improved tolerance of maize plants to salt stress by arbuscular mycorrhiza is related to higher accumulation of soluble sugars in roots. Mycorrhiza 12: 185-190.

FÜZY A., VOROS I., TAKACS T., TOTH T., BIRO B. 2001. Colonisation of arbuscular mycorrhizal fungi on Festuca pseudovina and Matricaria chamomilla in two Hungarian salt affected soils. Internat. Interdisciplinary Conf., North Univ. of Baia Mare, Scient. Bull. 25 (40): 109-117. 
HASEGAWA P.M., BRESSAN R.A., HANADA A.K. 1986. Cellular mechanisms of salinity tolerance. Hortic. Sci. 21: 1317-1324.

HILDEBRANDT U., JANETTA K., OUZIAD F., RENNE B., NAWRATH K., BOTHE H. 2001. Arbuscular mycorrhizal colonization of halophytes in Central European salt marshes. Mycorrhiza 10: 175-183.

HIRREL M.C., MEHRAVAN H., GERDEMANN J.W. 1987. Vesicular-arbuscular in the Chenopodiaceae and Cruciferae: do they occur? Can. J. Bot. 56: 2813-2817.

HIRREL M.C., GERDEMANN J.W. 1980. Improved growth of onion and dell pepper in saline soils by two vesicular-arbuscular mycorrhizal fungi. Soil. Sci. Soc. Am. J. 44: 654-655.

HO I. 1987. Vesicular-arbuscular mycorrhizae of halophytic grasses in the Alvard desert of Oregon. Northwest Sci. 61: 148-151.

KHAN A.G. 1974. The occurence of mycorrhizas in halophytes, hydrophytes and xerophytes, and of Endogone spores in adjacent soils. J. Gen. Microbiol. 81: 7-14

KOPCEWICZ J., LEWAK S. 1998. Podstawy fizjologii roślin. PWN Warszawa, pp. 611-613. (in Polish)

KOWALKOWSKI A., KRÓL H., OSTROWSKA A., SYTEK S., SZCZUBIEŁKA Z. 1973. Instrukcja laboratoryjna dla pracowni gleboznawczo-nawożeniowych. IBL. Warszawa-Sękocin, pp. 55-62. (in Polish)

LANDWEHR M., HILDEBRANDT U., WILDE P., NAWRATH K., TOTH T., BIRO B., BOTHE H. 2002. The arbuscular mycorrhizal fungus Glomus geosporum in European saline, sodic and gypsum soils. Mycorrhiza 12: 199-211.

LITYŃSKI T., JURKOWSKA H., GORLACH E. 1968. Analiza chemiczno-rolnicza. PWN, Warszawa, pp. 129-132. (in Polish)

MASON E. 1928. Note on the presence of mycorrhiza in the roots of salt marsh plants. New Phytol. 27: 193-195.

OJALA J.C, JARRELL W.M, MENGE J.A. 1983. Influence of mycorrhizal fungi on the mineral nutrition and yield of onion in saline soil. Agron. J. 75: 255-259.

OMAR M.B., BOLLAND L., HEATHER W.A. 1979. A permanent mounting medium for fungi. Bull. British Mycol. Soc. 13: 13-32.

ORŁOWSKA E., RYSZKA P., JURKIEWICZ A., TURNAU K. Effectiveness of arbuscular mycorrhizal fungal (AMF) strains in colonization of plants involved in phytostabilisation of zinc wastes. Geoderma. (in press)

OSTROWSKA A., GAWLIŃSKI S., SZCZUBIAŁKA Z. 1991. Metody analizy i oceny właściwości gleb i roślin. PWN, Warszawa, pp. 71-76, 199-211. (in Polish)
POND E.C., MERGE E., JARREL W.M. 1984. Improved growth of tomato in salinized soil by vesicular-arbuscular mycorrhizal fungi collected from saline soil. Mycologia 76: 74-84.

RICHARDS L.A. 1954. Diagnosis and improvement of saline and alkali soils. United States Department of Agriculture, Handbook NO 60, Washington DC, 60 p.

ROZEMA J., ARP W., VAN DIGGELEN J., VAN ESBROEK M., BROEKMAN R., PUNTE H., 1986. Occurrence and ecological significance of vesicular-arbuscular mycorrhiza in the salt marsh environment. Acta Bot. Neerl. 35: 457-467.

RUIZ-LOZANO J.M., AZCON R. 2000. Symbiotic efficiency of an autochtonous arbuscular mycorrhizal Glomus sp. from saline soils and Glomus deserticola under salinity. Mycorrhiza 10 (3): 137-143.

RUIZ-LOZANO J.M., AZCON R., GOMEZ M. 1996. Alleviation of salt stress by arbuscular-mycorrhizal Glomus species in Lactuca sativa plants. Physiol. Plant 98: 767-772.

SCHWARZ M., GALE J. 1984. Growth response to salinity at high levels of carbon dioxide. J. Exp. Bot. 35: 193-196.

SINGH R.P., CHOUDHARY A., GULATI A., DAHIYA H.C., JAIWAL P.K., SENGAR R.S. 1997. Response of plants to salinity in interaction with other abiotic factors. In: Strategies for improving salt tolerance in higher plants. Jawal P.K., Singh R.P., Gulati A. (eds) Science Publishers, Enfield, N.H., pp. 25-39.

SMITH S.E., READ D.J. 1997. Mycorrhizal Symbiosis. Academic Press, San Diego.

SZAFER W., ZARZYCKI K. 1970. Szata roślinna Polski. PWN Warszawa, pp. 237-250. (in Polish)

TROUVELOT A., KOUGH J.L., GIANINAZZI-PEARSON V. 1986. Mesure du taux de mycorhization VA d'un systeme radiculaire. Recherche de methodes d'estimation ayant une signification fonctionelle. Mycorrhizae: physiology and genetics - Les mycorhizes: physiologie et genetique. $1^{\mathrm{er}} \mathrm{ESM} / 1^{\mathrm{st}} \mathrm{SEM}$, Dijon, INRA, Paris pp. 217-221.

VAN AARLE I., OLSSON P., SÖDERSTRÖM B. 2001. Microscopic detection of phosphatase activity of saprophytic and arbuscular mycorrhizal fungi using a fluorogenic substrate. Mycologia 93 (1): 17-24.

VOLKMAR K.M., HU Y., STEPPUHN H. 1998. Physiological responses of plants to salinity: A review. Can. J. Plant Sci. 78: 19-27.

ZAHRAN H.H. 1996. Diversity, adaptation and activity of the bacterial flora in saline environments. Biol. Fertil. Soil 25: 211-223. 